\title{
Biological Activities of a Human Pluripotent Hemopoietic Colony-Stimulating Factor *
}

\author{
E. Platzer ${ }^{1}$, K. Welte ${ }^{2}$, L. Lu ${ }^{2}$, J. L. Gabrilove ${ }^{2}$, Y.-P. Yung ${ }^{2}$, C. F. Nathan ${ }^{3}$, \\ R.Mertelsmann ${ }^{2}$, and M.A.S. Moore ${ }^{2}$
}

\section{A. Introduction}

As described elsewhere in this volume by Welte et al., a human pluripotent hemopoietic colony-stimulating factor (CSF) was purified to apparent homogeneity from media conditioned by the human bladder carcinoma cell line, 5637. The purified material supports colony formation in vitro from human multipotential (CFUGEMM), early erythroid (BFU-E), granulocyte and monocyte (CFU-G, M) progenitor cells ${ }^{4}$. A murine CSF, Interleukin 3 or multi-CSF, with similar activities on normal mouse bone marrow [1,2], has recently been purified [3] and genetically cloned [4]. Interleukin 3 was originally detected by its ability to induce 20-alpha-OH-steroid dehydrogenase $(20 \alpha \mathrm{SDH})$ in cultured spleen cells of $n u / n u$ mice [5]. Later on it was discovered to have biological activities on a

Supported by NCI grant CA 32516, ACS grant CH3G, grant PI 103/1-1 from the Deutsche Forschungsgemeinschaft, and the Gar Reichman Foundation

1 Institut f. klin. Immunologie, Krankenhausstr. 12, D-8520 Erlangen, FRG

Henry Kaplan Award for the best poster Cellbiological Session

2 Laboratory of Developmental Hematopoiesis, and Laboratory of Molecular Hematology, Memorial Sloan-Kettering Cancer Center

3 Laboratory of Cellular Physiology and Immunology, The Rockefeller University, New York, N.Y. 10021, USA

4 CFU-GEMM, colony-forming unit granulocytes, erythrocytes, macrophages, and megakaryocytes; BFU-E, burst-forming unit erythroid; CFU-G, M, colony-forming unit granulocytes and macrophages wide range of hemopoietic cells: progenitor cells of erythrocytes, megakaryocytes, granulocytes, monocytes and eosinophils, mast cells and their precursors, and possibly lymphocytes [2, 6-8]. Since come activities of Interleukin 3 and pluripotent CSF, or Pluripoietin, on hemopoietic progenitor cells appeared similar, we screened for additional biological effects of Pluripoietin.

\section{B. Pluripoietin Supports In Vitro Development of Precursors of Colony- Forming Progenitor Cells}

Normal human bone marrow cells taken from volunteers after informed consent were separated by density gradient centrifugation on Ficoll, adherence to plastic surfaces and depletion of cells rosetting at $4^{\circ} \mathrm{C}$ with neuraminidase-treated sheep red blood cells. When this cell population was cultured in methylcellulose as described [9], Pluripoietin in the absence of phytohemagglutinin-stimulated lymphocyteconditioned medium (PHA-LCM) supported colony formation from CFU-GEMM and BFU-E, suggesting that pluripotent CSF acts directly on early progenitor cells, not via macrophages or T-lymphocytes as accessory cells of hematopoiesis. In agar cultures [10], Pluripoietin induced mostly neutrophil colonies by day 7 , and neutrophil, macrophage, and mixed neutrophil/macrophage colonies as well as some eosinophil clusters by day 14. Furthermore, Pluripoietin induced the development of immature precursors of colonyforming progenitor cells of granulocytes 
and macrophages [11]. This was studied by incubating low-density, nonadherent, and T-cell-depleted marrow cells in liquid culture in the presence of Pluripoietin for 7 days prior to agar culture, in a granulocytepotentiating activity ( $\triangle \mathrm{GPA})$-type [12] or precursor of CFU-G, $M$ progenitor cell (pre-CFU-c) [13] assay. There are no reports of Interleukin 3 tested in such assays, but it appears to have a similar effect on murine stem cells in vitro prior to transplantation [14].

\section{Pluripoietin Acts on Mature Hemopoietic Cells}

Normal human peripheral blood monocytes were isolated by adherence procedures as described [15]. When cultured in the presence of Pluripoietin from day 1 through 4, monocytes/macrophages showed marked spreading and an increase of adherent cell protein, suggesting increased protein synthesis as compared with untreated controls [11]. This effect was not seen when Pluripoietin was added at day 4 of culture or later, possibly because macrophages produce their own CSF. Pluripoietin did not increase the production of $\mathrm{H}_{2} \mathrm{O}_{2}$-producing enzymes or anti-Toxoplasma activity in macrophages when added after 3 days of culture [15]. Interleukin 3 was not reported to be active on macrophages, but its activity in supporting long-term growth in vitro of natural cytotoxic effector cells [16] and histamine-producing cells [6] may reflect activities on mature hemopoietic cells.

\section{Pluripoietin Induces Differentiation in Leukemic Cell Lines}

Differentiation of leukemic cell lines in vitro can be achieved by a variety of nonphysiologic [e.g., dimethylsulfoxide (DMSO), phorboldiesters] and physiologic (e.g., retinoic acid, vitamin $D_{3}$ ) inducers [17]. Murine granulocyte-CSF (G-CSF) is known to be a potent inducer of differentiation of WEHI-3B $(\mathrm{D}+)$ murine myelomonocytic leukemia cells, whereas Interleukin 3 lacks this activity (for review, see [1]). We tested Pluripoietin for leukemia-differentiating activity (GM-DF, leukemia-differentiating activity for granulocyte and macrophage pathway) in a clonal assay system described by Metcalf [18], using murine WEHI-3B (D+) and human HL-60 promyelocytic leukemia cell lines [11]. Quantitation of GM-DF was obtained by incubation of leukemic cells in agar with serial dilutions of pluripotent CSF. Pluripoietin had GM-DF activity on both cell lines. However, HL-60 required approximately fivefold higher concentrations of Pluripoietin to achieve 50\% differentiated, spreading colonies versus undifferentiated tight blast-cell colonies than did WEHI-3B $(\mathrm{D}+)$ [11]. The human leukemia cell line $\mathrm{KGl}$ (courtesy Dr. H.P. Koeffler) responded to Pluripoietin with increased colony formation in agar and increased $\left[{ }^{3} \mathrm{H}\right]$ thymidine incorporation after $24-48 \mathrm{~h}$ in suspension culture. This might indicate that the GM-DF activity of Pluripoietin reflects the differentiating capacity of leukemia cell lines rather than an intrinsic property of the factor.

Table 1. Murine mast-cell growth factor activity of Pluripoietin

\begin{tabular}{lcc}
\hline Stimulator & $\begin{array}{l}\left.{ }^{3} \mathrm{H}\right] \text { thymi- } \\
\text { dine uptake } \\
(\mathrm{cpm})\end{array}$ & $\begin{array}{l}{\left[{ }^{3} \mathrm{H}\right] \text { thymi- }} \\
\text { dine uptake } \\
(\% \text { max })\end{array}$ \\
\hline ConA-LBRM CM & & \\
$1: 4$ & $5617 \pm 12^{\mathrm{a}}$ & 100 \\
$1: 8$ & $4416 \pm 661^{\mathrm{a}}$ & 79 \\
$1: 16$ & $2987 \pm 70^{\mathrm{a}}$ & 53 \\
Medium & $164 \pm 64$ & 2.9 \\
Pluripoietin & & \\
$500 \mathrm{U} / \mathrm{ml}$ & $344 \pm 87^{\mathrm{b}}$ & 6.7 \\
$250 \mathrm{U} / \mathrm{ml}$ & $594 \pm 153^{\mathrm{b}}$ & 11.5 \\
$125 \mathrm{U} / \mathrm{ml}$ & $485 \pm 214^{\mathrm{c}}$ & 9.4 \\
$63 \mathrm{U} / \mathrm{ml}$ & $380 \pm 105^{\mathrm{b}}$ & 7.4 \\
\end{tabular}

Results are expressed as mean \pm 1 standard deviation of triplicate cultures.

Significance of difference from medium control cultures (Student's $t$-test):

$\begin{array}{ll}\text { a } & 2 P<0.001 \\ \text { b } & 2 P<0.05 \\ \text { c } & 2 P<0.1\end{array}$ 
Table 2. Biological activities of purified human Pluripoietin and murine Interleukin 3

\begin{tabular}{|c|c|c|}
\hline Activity & $\begin{array}{l}\text { Pluri- } \\
\text { poietin }\end{array}$ & $\begin{array}{l}\text { Inter- } \\
\text { leukin } 3^{b}\end{array}$ \\
\hline \multicolumn{3}{|l|}{$\begin{array}{l}\text { Clonal growth of } \\
\text { hemopoietic progenitors: }\end{array}$} \\
\hline CFU-GEMM & + & + \\
\hline BFU-E & + & + \\
\hline CFU-G, M, GM & + & + \\
\hline CFU-EOS & + & + \\
\hline CFU-MEG & NT & + \\
\hline prẹ-CFU-c ( $\triangle \mathrm{GPA})$ & + & NT \\
\hline $\begin{array}{l}\text { Stem-cell multiplication } \\
\text { (CFU-s) }\end{array}$ & d & + \\
\hline Species cross-reactivity $^{c}$ & \pm & - \\
\hline \multicolumn{3}{|l|}{$\begin{array}{l}\text { Leukemia-differentiating } \\
\text { activity (GM-DF) on: }\end{array}$} \\
\hline WEHI-3B (D+) & + & - \\
\hline HL60 & + & - \\
\hline \multicolumn{3}{|c|}{$\left[{ }^{3} \mathrm{H}\right]$ thymidine uptake in cell lines: } \\
\hline KG1 & + & - \\
\hline FDC-P2 & - & + \\
\hline $\begin{array}{l}\text { Murine mast-cell lines } \\
\text { (MCGF activity) }\end{array}$ & \pm & + \\
\hline Histamine production & NT & + \\
\hline $\begin{array}{l}\text { Protein synthesis of } \\
\text { mature macrophages }\end{array}$ & + & NT \\
\hline Induction of $20 \mathrm{aSDH}$ & d & + \\
\hline \multicolumn{3}{|l|}{ Growth of: } \\
\hline Natural cytotoxic cells & d & + \\
\hline Pre-B-cell clones & NT & + \\
\hline
\end{tabular}

a Pluripoietin was tested on human target cells, if not noted otherwise

b Interleukin 3 activity on murine target cells, if not noted otherwise. Data derived from literature, except GM-DF and activity on KG1

c Activity on bone-marrow-derived colony formation in agar cultures

d No human test system available

NT, not tested

\section{E. Pluripoietin Shows Minimal Species Cross-Reactivity on Murine Cells}

Normal mouse bone marrow cells cultured in agar for 7 days in the presence of saturating concentrations of Pluripoietin formed approximately $10 \%$ of the colonies supported by WEHI-3B-conditioned media as a standard source of CSF(s). All colonies formed in the presence of Pluripoietin were of similar morphology, not staining for alpha-naphthyl-acetate esterase or Kaplow's myeloperoxidase; this suggests that only a subpopulation of murine colony-forming progenitors is responsive to Pluripoietin. Weak cross-species activity was also found on continuous murine mast-cell lines, established as described from murine longterm bone marrow cultures [19]. Five thousand cells per well of a mast-cell growth factor (MCGF)-dependent murine mastcell line were incubated for $24 \mathrm{~h}$ at $37^{\circ} \mathrm{C}$ in 96 well plates with serial dilutions of growth factors and then assayed for $\left[{ }^{3} \mathrm{H}\right]$ thymidine uptake as described [20]. The results are given in Table 1 and demonstrate little more than $10 \%$ murine MCGF activity of Pluripoietin as compared with ConA-LBRM CM (concanavalin-Astimulated conditioned media from LBRM murine lymphoma line), which was used as a standard preparation of murine MCGF. 
The murine Interleukin-3-dependent cell line FDC-P2 (courtesy Dr. M. Dexter) did not respond with increased $\left[{ }^{3} \mathrm{H}\right]$ thymidine uptake to concentrations of Pluripoietin as high as $2000 \mathrm{U} / \mathrm{ml}$ (data not shown).

\section{F. Conclusion}

Table 2 gives a summary of biological activities of Pluripoietin and Interleukin 3. Comparison is incomplete, since for some activities of Interleukin 3 on murine cells there exist no equivalent human assay systems, as for instance long-term mast-cell lines. From the results obtained so far, leukemia-differentiating activity is a most remarkable property of Pluripoietin, distinguishing it from murine Interleukin 3, which lacks this activity [1]. In addition, Pluripoietin is active on a wide range of hemopoietic cells, with respect to cell lineage and to their place in the hierarchy of stem cells to mature cells. The availability of purified human hemopoietic growth factors should facilitate future studies of complex regulatory mechanisms in hematopoiesis.

\section{References}

1. Nicola NA, Vadas M (1984) Hemopoietic colony-stimulating factors. Immunol Today 5:76-81

2. Watson JD, Prestidge RL (1983) Interleukin 3 and colony-stimulating factors. Immunol Today 4:278-280

3. Ihle JN, Keller J, Henderson L, Klein F, Palaszynski E (1982) Procedures for the purification of Interleukin 3 to homogeneity. J Immunol 129:2431-2436

4. Fung MC, Hapel AJ, Ymer S, Cohen DR, Johnson RM, Campbell HD, Young IG (1984) Molecular cloning of c-DNA for murine interleukin 3. Nature 307:233-237

5. Ihle JN, Pepersack L, Rebar L (1981) Regulation of $T$ cell differentiation: in vitro induction of 20-alpha-steroid dehydrogenase in splenic lymphocytes is mediated by a unique lymphokine. J Immunol 126:2184 $-2189$

6. Ihle JN, Keller J, Oroszlan S, Henderson LE, Copeland TD, Fitch F, Prystowski MB, Goldwasser E, Schrader JW, Palaszynski E, Dy M, Lebel B (1983) Biologic properties of homogeneous Interleukin 3. J Immunol 131:282-287

7. Razin E, Ihle JN, Seldin D, Mencia-Huerta JM, Katz HR, Leblanc PA, Hein A, Caulfield JP, Austen KF, Stevens RL. Interleukin 3: a differentiation and growth factor for the mouse mast cell that contains chondroitin sulfate $\mathrm{E}$ proteoglycan. J Immunol 132: 1479-1486

8. Palacios R, Henson G, Steinmetz M, McKearn JP (1984) Interleukin 3 supports growth of mouse pre-B-cell clones in vitro. Nature 309: 126-131

9. Lu L, Broxmeyer HE, Meyers PA, More MAS, Thaler T (1983) Association of cell cycle expression of Ia-like antigenic determinants on normal human multipotential (CFU-GEMM) and erythroid (BFU-E) progenitor cells with regulation in vitro by acidic isoferritins. Blood 61:250-256

10. Broxmeyer HE, Moore MAS, Ralph P (1977) Cell-free granulocyte colony inhibitory activity derived from human polymorphonuclear neutrophils. Exp Hematol 5:87-102

11. Platzer E, Welte K, Gabrilove JL, Lu L, Nathan CF, Mertelsmann R, Moore MAS (to be published) Biological activities of a human pluripotent colony stimulating factor on normal and leukemic cells

12. Hoang T, Iscove NN, Odartchenko N (1983) Macromolecules stimulating human granulocytic colony-forming cells, precursors of these cells, and primitive erythroid progenitors: some apparent nonidentities. Blood 61:960-966

13. Jacobsen N, Broxmeyer HE, Grossbard E, Moore MAS (1979) Colony-forming units in diffusion chambers (CFU-d) and colonyforming units in agar culture (CFU-c) obtained from normal human bone marrow: a possible parent-progeny relationship. Cell Tissue Kinet 12:213-226

14. Wagemaker G, Dorssers L (1984) Properties of purified stem cell activating factor (SAF) and its use for selective multiplication of stem cells for bone marrow transplantation in mice. Exp Hematol 12:454 (abstract 247)

15. Nathan $C F$, Prendergast TJ, Wiebe ME, Stanley ER, Platzer E, Remold HG, Welte K, Rubin BY, Murray HW (1984) Activation of human macrophages. J Exp Med 160:600 $-605$

16. Djeu JY, Lanza E, Pastore S, Hapel AJ (1983) Selective growth of natural cytotoxic but not natural killer effector cells in interleukin 3. Nature 306:788-791

17. Koeffler HP (1983) Induction of differentiation of human acute myelogenous leukemia cells: therapeutic implications. Blood 62:709-721 
18. Metcalf D (1980) Clonal extinction of myelomonocytic leukemic cells by serum from mice injected with endotoxin. Int $J$ Cancer 25:225-233

19. Tertian G, Yung YP, Guy-Grand D, Moore MAS (1980) Long-term culture of murine mast cells. I. Description of a growth factor dependent in vitro culture technique. J Immunol 127:788-794

20. Yung YP, Eger R, Tertian G, Moore MAS (1981) Long-term in vitro culture of murine mast cells, II. Purification of a mast cell growth factor and its dissociation from TCGF. J Immunol 12:794-799 